傍気管リンパ節転移による反回神経麻痺をきたした 不顕性甲状腺癌症例

宮原 裕*. 鶴田 至宏*·佐藤 武男
吉野 邦俊・馬谷 克則

\title{
A Case of Occult Thyroid Cancer Causing Recurrent Palsy due to Paratracheal Metastasis
}

\author{
Hiroshi Miyahara and Yoshihiro Tsuruta \\ (Nara Medical University) \\ Takeo Sato, Kunitoshi Yoshino and Katsunori Umatani \\ (The Center for Adult Diseases, Osaka)
}

\begin{abstract}
A 38-year-old male with occult thyroid cancer is reported. The patient visited our hospital complaining of hoarseness for about one month. A direct laryngoscopy showed right recurrent palsy. In further examination, no thyroid tumor, hypopharyngeal tumor or other lymph node swelling were detected. Seven months later, right neck lymph node swelling improved. By neck dissection, metastasis of thyroid papillary adenocarcinoma was detected. Right hemithyroidectomy was then performed. A tiny lesion of the thyroid gland was detected, and it also became clear that the patient's recurrent palsy was due to metastasis to the paratracheal lymph node.

The importance of precise follow-up in cases of ill-defined recurrent palsy is stressed.
\end{abstract}

Key words: paratracheal metastasis, recurrent palsy, occult thyroid cancer

はじめに

甲状腺癌は乳頭腺癌が多く, 手術による成績 も比較的良い。㐬た不顕性の甲状腺癌は他疾患 の剖検例の病理的検索から, かなりの高頻度で あることが認められている。したがって甲状腺 癌の生物学的特性については非常に関心がもた れている。
われわれは今回, 反回神経麻痺による嗄声を きたし，種々の検査にて原病巣が確定できなか ったが，その後不顕性甲状腺癌の傍気管リンパ 節転移によるものと判明したきわめて稀な興味 ある症例を経験したので文献的考察を加え報告 する。

大阪府立成人病センター耳鼻咽喉科（主任：佐藤武男総長）

* 現 : 奈良県立医科大学耳鼻咽喉科学教室 (主任 : 松永 喬教授) 


\section{症例}

- 38 歳, 男性, 会社員.

(初診：昭和59年 5 月 30 日)

主 訴 : 嗄声.

既往歴：特記すべきことなし。

家族歴：特記すべきことなし。

嗜好歴：タバュ；40本/日×18年, 飲酒 $(-)$ 現病歷：初診の約 1 力月前よりとくに誘因な く，急に嗄声扣よび誤嚥をきたした。咽頭痛, 曣下痛は訴えなかった。

耳鼻科的所見：間接喉頭鏡検査にて右反回神 経麻痺を認めた（副正中位）。さらに右梨状窩 に唾液の貯留を認めた。他に咽喉頭をファイ バースュープにて観察したが著変を認めなかっ た。また甲状腺腫大や腫溜の徴候もなかった。 反回神経麻痺以外他の脳神経症状は認めなかっ た。

検査成績 : 胸部 $\mathrm{X}$ 線, 食道造影検査にて異常 所見なし、喀痰細胞診（3 回）異常なし。アイ ソトープ $\mathrm{Ga}$ 検査にても異常は認めなかった。

経過：原疾患の同定が出来ないため，一応特 発性反回神経麻痺として薬物加療を続けながら， 下咽頭癌をはじめとする悪性腫瘍の有無を重要 なチェックポイントとして，その後定期的に経 過を観察していた。

約 7 カ月後に右上拈よび下深頸部リンパ節腫 大をきたした．そこで改めて Ga シンチ， CT 検查（図 1) を行ったところ触診と同じ部位の リンパ節の陰影を認めるのみで，他に異常所見

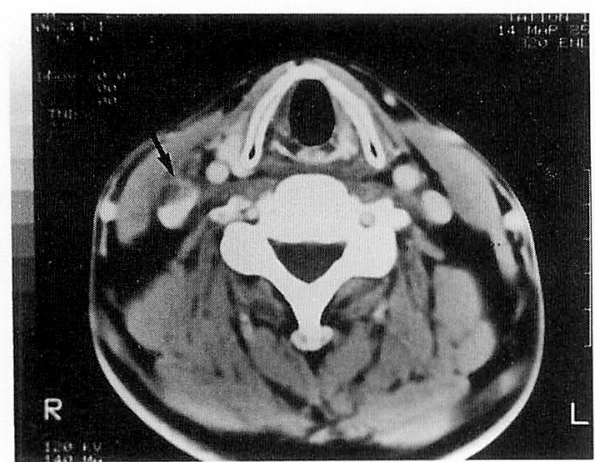

図1 右頸部リンパ節転移を示すX線 CT 像
を認めなかった。そのため，一応原発巣不明転 移癌として昭和 60 年 3 月 18 日右頸部リンパ節廓 清術を行った。 術中の下深頸部リンパ節の迅速 凍結病理検査に拈いて乳頭腺癌の診断を得た (図 2 )。そこで右頸部リンパ節廓清術を完了し た後, 甲状腺を両葉とも十分触診したが，とく に小結節は触知できず, 結局甲状腺右葉切除術 を行った。

その割面標本にて，下極近くに直径約 $1 \mathrm{~mm}$ 大の原発巣と思われる白色病変を認めた（図 3)。な拉傍気管リンパ節（径 $3 \mathrm{~mm}$ 硬）を認 め, それは反回神経に直接浸潤して拈り，これ が反回神経麻痺の原因と考光られた（図 4).

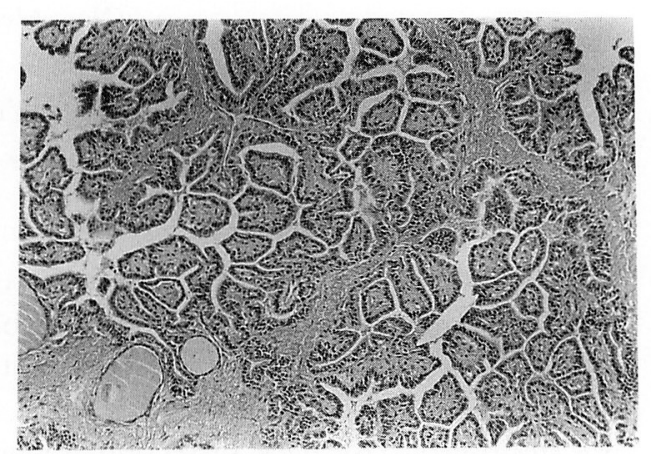

図 2 右頸部リンパ節転移生検病理組織像 (乳頭線癌 $\times 100$ H.E.)

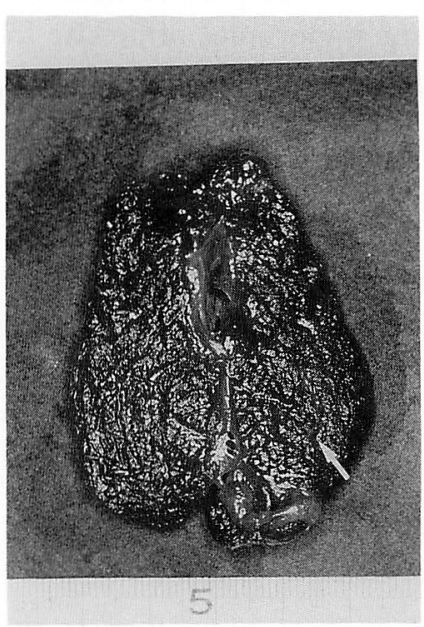

図 3 摘出甲状腺右葉内の小癌巣（矢印） 
な打微小病巣検索のため, 術後連続切片標本を 作成して検索したところ，他に径 $1 \mathrm{~mm}$ 大と 1 $\mathrm{mm}$ 以下の計 3 ケ所の微小癌巣を認めた（図 5 ). その後, 約 3 年 6 力月を経過しているが 再発，転移は認めていない。

\section{考案}

われわれの施設では最近 8 年間に扱った甲状 腺癌のうち, 臨床的に detectable であったも のは99例であり，他の喉頭癌や下咽頭癌の手術 の際に甲状腺癌小病巣が発見されたいわゆる

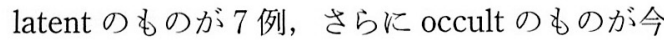

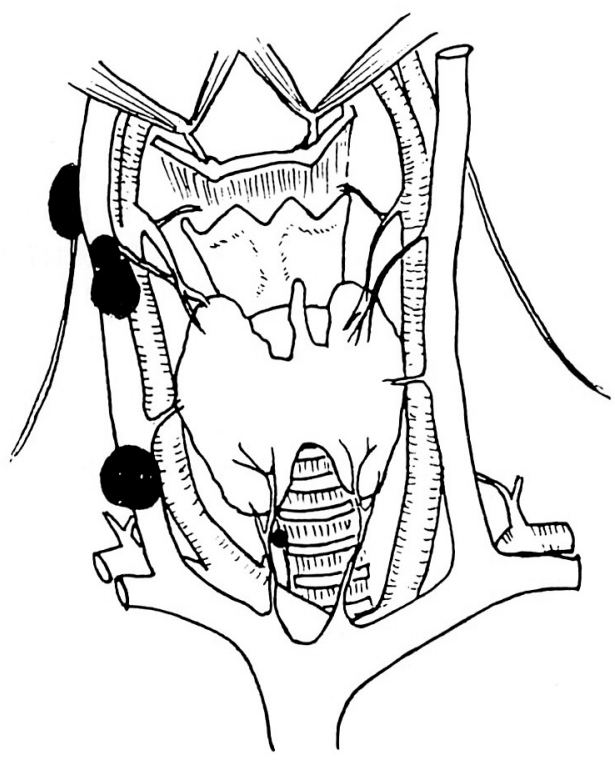

図4 頸部リンパ節転移所見 右傍気管リンパ節が反回神経に浸潤していた

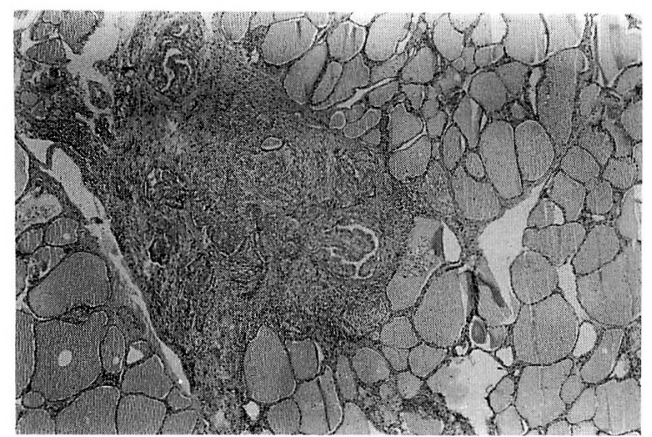

図 5 甲状腺右葉内の微小癌 $(\times 40$, H.E. $)$
回報告した症例を入れて 3 例であった。

他の 2 例は喉頭癌の手術の際に転移りンパ節 を術後病理検査で認めたものである（表 1 ）。

文献的にみてみると，頸部リンパ節転移ある いは遠隔転移ではじめて甲状腺癌の存在が診断 された症例の報告は，国内外をとわず少なから ずみられる1 3)。をた甲状腺癌は余りに微小病 変のため，あるいは進行がきわめてゆっくりの ため担癌状態でありながら，終生発見されるこ となく経過することもみられるのが特徵である． さらに放射線誘発癌としての甲状腺癌の頻度も 高いことが報告されており，剖検に拈ける latent の甲状腺癌の頻度が各国で報告されてい る。しかしその頻度はは5.6\%から $35.6 \%$ と国， 地方によって差がある（表 $2^{4 \sim 9)}$ )。 しかも latent の甲状腺癌が高頻度の国が必ずしも顕性 甲状腺癌の高頻度国でもないのが特徴である.

われわれは，かつて頸部リンパ節結核や頸部 皮䖉湿疹にたいして放射線治療が行われた症例 の場合, 放射線誘発癌の症例, いわゆる latent の甲状腺癌が認められることがあることから， 喉頭癌, 下咽頭癌の手術の際には注意して甲状 腺を十分触診し小結節の有無の検索を行ってい る.

今回の症例は通常みられるような反回神経に 原発癌が直接浸潤したものではなく, 原発癌が

表 1 甲状腺癌症例 (CADO, 1978-1985)

1. Clinically detectable ca. (99 cases)

Sex : male

female 77

Age : 21-80 yrs

Pthology : papillary ad. ca. follicular ad. ca. 9 medullary ca. 3 undiff. ca. 2 malignant lymphoma 3

2. Latent ca. 7 cases $\left\{\begin{array}{l}\text { papillary ad. ca. } 3 \\ \text { follicular ad. ca. }\end{array}\right.$

3. Occult ca. 3 cases papillary ad. ca.

Occult ca. 3 cases $\left\{\begin{array}{l}\text { papillary adicular ad. ca. } 2 \\ \text { follicula } 2\end{array}\right.$ 
径 $1 \mathrm{~mm}$ にもみたない微小癌であり傍気管部の 外から触知し難い小さな転移性リンパ節が反回 神経に直接浸潤し反回神経麻痺をきたした特異 的な occult 甲状腺癌症例であった。

な敃改めて不顕性癌 (occult cancer) と潜伏癌 (latent cancer) について定義をみてみると，前 者は転移巣から原発巣の所在が発見されたもの であり，後者は他疾患により摘出された甲状腺 中にたまたま発見されるもので，径 $1 \mathrm{~cm}$ 以下 の微小癌と定められている (甲状腺癌取扱い規 約，第 3 版，198810)).

本症例はその定義からみると，不顕性癌とい えるが, 最初, 転移リンパ節の腫大が明らかで なく, 微小な傍気管リンパ節転移が直接反回神 経を侵し，嗄声といら症状を来したといら点で 特異である。

したがって, 反回神経麻瘏患者の診断, 治療 にあたっては，安易に特発性の麻痷としてしま らことなく，長期にわたる経過観察が重要であ る. 当センターでの反回神経麻痺の原因別内訳 は表 3 のごとくであるが，癌センターの特徵と いえば肺癌, 食道癌などの悪性腫瘍によるもの が多いのが特徵である。原因不明と一応なって いる症例の長期間の経過観察がなされると原因 疾患がはっきりするものもあるといえる，今回 の症例は今後, 反対側の腺内転移の有無, さら に頸部リンパ節の転移に注意しながら経過観察 の必要がある.

$$
\text { まとめ }
$$

38歳の男性で嗄声を主訴とし, 反回神経麻痺 の所見が得られたが，原発病巣を同定できず， その後の経過で不顕性の甲状腺癌であり, 麻痺 の原因は微小な傍気管リンパ節転移の反回神経 への直接浸潤であったきわめてまれな症例を報 告した．反回神経麻痺の患者をみた場合，積極

表 3 反回神経マヒの原因別頻度

(CADO, 1978.1. 1982.6)

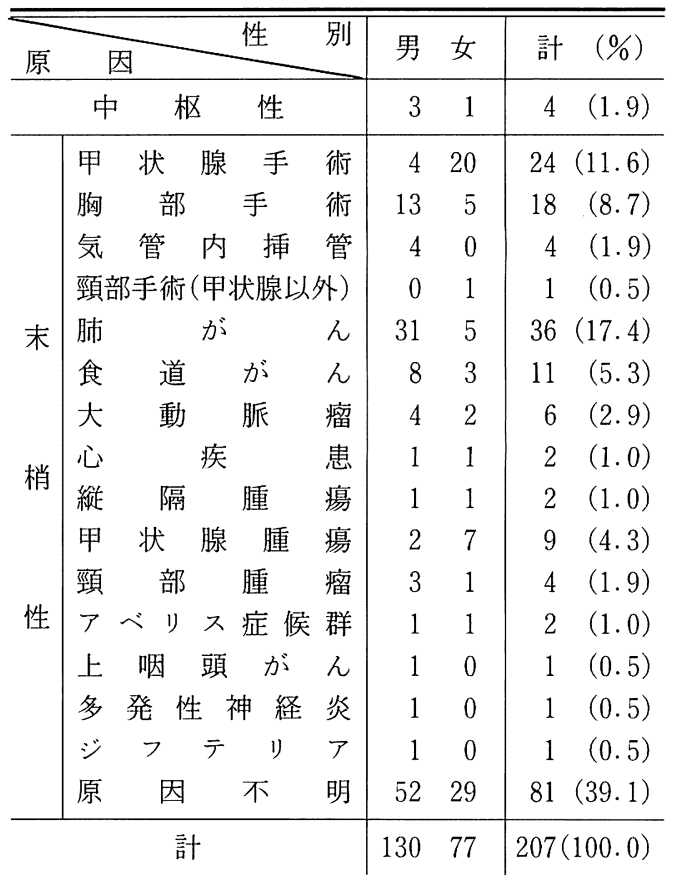

表 2 剖検にお㹁る不顕性癌の頻度（文献4) -9)による）

\begin{tabular}{l|c|c}
\hline \hline & No. of autopsies & Prevalence rate \\
\hline Hawaii (1975) & 248 & $28.1(\%)$ \\
Japan (Sendai, 1975) & 102 & 28.4 \\
Japan (Hiroshima \& Nagasaki, 1977) & 391 & 28.4 \\
Canada (Ontario, 1975) & 100 & 6.0 \\
Poland (Gliwice, 1975) & 110 & 9.0 \\
Colombia (Cali, 1975) & 607 & 5.6 \\
USA (Michigan, 1977) & 100 & 13.0 \\
Japan (Mie, 1978) & 43 & 16.3 \\
Finland (1985) & 101 & 35.6
\end{tabular}


的に原因疾患を検索することも大切であるが， さらに長期間にわたる経過観察も肝要であるこ とを指摘した。

なお本論文の内容は第10回頭頸部腫瘍学会にて報 告した。

\section{参考文献}

1）市川敏郎，青柳和彦，竹村和郎，他：不顕性甲 状腺癌 (occult thyroid carcinoma) の 2 症例. 診断と治療 $65: 2345 \sim 2350,1977$.

2）田中忠良, 宮原義門, 森繁一郎, 他 : 甲状腺微 小癌の 3 例. 日臨外会誌 $40: 446 \sim 452,1979$.

3) Strate SM, Lee EL and Childers JH : Occult papillary carcinoma of the thyroid with distant metastases. Cancer 54 : 1093 1100, 1984.

4）矢谷隆一, 坂倉康夫 : 浅在性甲状腺癌の有病率 およびその臨床病理学的意義. 医学々生物学 $97: 385 \sim 388,1978$.

5) Harach HR, Franssila KO and Wasenius VM : Occult papillary carcinoma of the thyroid. A "normal" finding in Finland. A systematic autopsy study. Cancer $56: 531 \sim 538,1985$.
6) Bondenson $\mathrm{L}$ and Ljungberg $\mathrm{O}$ : Occult thyroid carcinoma at autopsy in Malmo. Sweden. Cancer $47:$ 319 323, 1981.

7) Fukunaga $\mathrm{FH}$ and Yatani R : Geographical pathology of occult thyroid carcinomas. Cancer $36:$ 1095 1099, 1975.

8) Nishiyama RH, Ludwing GK and Thompson NW : The prevalence of small papillary thyroid carcinomas in 100 consecutive necropsies in an American population. Radiationassociated thyroid carcinoma, (ed by DeGroot LI). pp123 135, Grune \& Stratton, New York, 1977.

9) Samkpson RJ : Prevalence and significance of occult thyroid cancer. Radiation-associated thyroid carcinoma (ed by Degroot LI). pp137 153, Grune \& Stratton, New York, 1977.

10）甲状腺外科検討会編：外科-病理甲状腺癌取扱 い規約（第 3 版）。金原出版，東京， 1988 .

$$
\left(\begin{array}{l}
\text { 別刷請求先 : 宮原 裕 } \\
\text { 厂6 } 634 \text { 橿原市四条町 } 840 \\
\text { 奈良県立医科大学耳鼻咽喉科学教室 }
\end{array}\right)
$$

